\title{
CHARACTERIZATION OF AN EXPERIMENTAL CELL IN A MUNICIPAL SOLID WASTE LANDFILL USING 2-D ELECTRICAL PROFILING TECHNIQUE
}

\author{
Antonio Carlos de Siqueira Neto ${ }^{1}$ and Vagner Roberto Elis ${ }^{2}$
}

\begin{abstract}
The electrical resistivity method (ER) with the electrical profiling technique (EP) were applied to landfill Delta A, located next to the highway dos Bandeirantes in Campinas (São Paulo, Brazil). Within the landfill there is a region of approximately 5,200 $\mathrm{m}^{2}$ called "experimental cell" with waterproofing base through HDPE (High Density Polyethylene) geomembrane which is regular monitoring by the UNICAMP Geotechnical Department. The main objective was to verify how the body of waste and the geomembrane are imaged with EP technique, and if there is evidence of leachate concentration areas and how the images would be if there was rupture of the geomembrane leaking. In the area were performed 6 lines with a length of $110 \mathrm{~m}$ and $12 \mathrm{~m}$ spacing between them using dipole-dipole array with electrode spacing of $4 \mathrm{~m}$ and $5 \mathrm{~m}$. The survey provides information about the experimental cell, identifying the resistive layer (geomembrane) and allowed us to compare the data with simulations in the laboratory. Subsequently, due to the concentrations of slurry generating points of high conductivity values, it is advisable to use other methodologies such as the ground penetrating radar (GPR) and the electromagnetic (EM-34), to compare the data obtained with the method used in this survey.
\end{abstract}

Keywords: electrical resistivity, landfill, experimental cell.

RESUMO. 0 método de eletrorresistividade (ER) utilizando a técnica de caminhamento elétrico (CE) foi aplicado no aterro Delta A, localizado ao lado da rodovia dos Bandeirantes no município de Campinas (SP). Dentro do aterro há uma região de aproximadamente $5.200 \mathrm{~m}^{2}$ denominada "célula experimental", com impermeabilização de base por meio de geomembrana de PEAD (Polietileno de alta densidade) onde ocorre um monitoramento regular pelo Departamento de Geotecnia da UNICAMP. Esse projeto teve como objetivo principal verificar como o corpo de resíduos e a geomembrana são imageados com a técnica de CE, e se existe evidência de zonas de concentração de chorume e como seriam as imagens caso houvesse ruptura da geomembrana com vazamento. Na área foram executadas 6 linhas com extensão de $110 \mathrm{~m}$ e espaçamento equidistante de $12 \mathrm{~m}$, utilizando arranjo dipolo-dipolo com espaçamento entre eletrodos de $4 \mathrm{~m}$ e $5 \mathrm{~m}$. 0 levantamento de CE forneceu informações precisas sobre a célula experimental, identificando a camada resistiva (geomembrana), e a ausência de vazamento do chorume e nos permitiu comparar os dados com simulações feitas em laboratório. Posteriormente, éaconselhável utilizar outras metodologias como o georadar (GPR) e o método eletromagnético (EM-34) para comparar os dados obtidos com a utilização do método ER neste levantamento.

Palavras-chave: resistividade elétrica, aterro sanitário, célula experimental.

\footnotetext{
1 Universidade Federal do Oeste do Pará, Instituto de Engenharia e Geociências, Rua Vera Paz, s/n, Salé, 68035-110 Santarém, PA, Brazil. Phone: +55(93) 99231 -3042 - E-mail: antonio.siqueira@ufopa.edu.br

2 Universidade de São Paulo, Instituto de Astronomia, Geofísica e Ciências Atmosféricas, Rua do Matão, 1226, Cidade Universitária, 05508-090 São Paulo, SP, Brazil. Phone: +55(11) 3091-4749 - E-mail vagnelis@iag.usp.br
} 


\section{INTRODUCTION}

The significant increase in world population has created great impact and challenges for the next generation, production and disposal of solid waste is one of them. The amount of this waste in the world is around 12 billion tons/year and by 2020 the expected volume is 18 billion tons/year (UNEP-EEA, 2007). In Brazil the issue is the same and waste generation increased by 1.3\% from 2011 to 2012 and, production for the year 2012 was approximately 63 million tonnes (ABRELPE, 2012). The Ministry of Environment in 2010 created the National Policy on Solid Waste (NPSW) which intends to implement landfills in all Brazilian municipalities which are found overcrowded in some municipalities and in others are absent.

The management of MSW (Municipal Solid Waste) has been a real chalenge for public managers due to problems such as available areas, environmental licensing, transportation costs, among others. According to the National Basic Sanitation Survey (IBGE, 2010), the current situation of Brazilian municipalities concerning the final disposal of municipal solid waste is: $50.8 \%$ of Brazilian municipalities dump solid waste in landfills, $22.5 \%$ dispose in controlled landfills, $27.7 \%$ use the landfill for disposal.

Several studies of groundwater pollution shows that all dump or controlled landfill causes some kind of pollution. Thus, concerns such as contamination of soil and water resources, plants, animals and man, as a result of the presence of metal contaminants from the improper disposal of solid waste, lead the researchers to focus their research objectives to these problems (Oliveira \& Pasqual, 2004).

The omission of the surveillance authority or the simple indifference of the population, often result in the illegal disposal of waste, usually in inappropriate areas, such as springs, rivers and areas of permanent protection. The slurry generation (liquid pollutant generated from the decomposition of organic residues) can exceed fifteen years after the end of the deposition of waste, depending on several factors (Possamai et al., 2007). If the soil under the waste is permeable and unprotected, the slurry can reach the water level, thus, contaminate aquifers in the nearby.

Currently geophysical methods have been widely used in the contamination plume studies because of its speed and relatively low cost when compared to other investigative techniques. The main geophysical methods for the investigation of contaminants are: Electromagnetic, Electrical Resistivity, Spontaneous Potential, Penetrating Radar Soil and eventually Magnetics (CETESB, 2001).

This project was developed in the landfill Delta A in Campinas (SP), which receives all MSW. In this landfill there is na experimental cell implanted and monitored by the Geotechnical Department of Unicamp (University of Campinas). The effluent flow control in the cell indicates possible slurry accumulations. Though, the use of resistivity method is ideal to identify slurry pockets due to the resistivity contrast in the middle, the structure of the experimental cell can be a limiting factor, since HDPE (High Density Polyethylene) is an electric insulating material.

During the development of the research, mathematical models were made simulating the situations created in the Experimental Cell and later compared with the sections obtained through the actual tests. This comparison will be important for evaluating the performance of the methodology used.

According to all these factors, the main objective was to verify how the body of waste and the geomembrane are imaging with electrical resistivity, if there is evidence of leachate concentration areas and how would the images be in case of a geomembrane rupture with leachate leaking. Therefore, it is expected the manufacture of a geoelectrical model ideal for the research area.

\section{SITE DESCRIPTION}

\section{Location of the experimental cell}

The study area is located in an experimental cell inside the Delta A sanitary landfill in the city of Campinas-SP, about $20 \mathrm{~km}$ from the city center and close to the Bandeirantes Highway. The route of access is the side road coming from Av. John Boyd Dunlop (Fig. 1). The landfill Delta A receives all municipal solid waste in the city of Campinas and has had its time of use extended several times.

This experimental cell was made for geomechanical studies of municipal solid waste and geo-environmental by researchers from Unicamp. And although it has been installed in accordance with the existing precepts of the engineering landfill, its operation does not occur properly. In the 5 locations where there is control of the slurry flow, two have a low flow, indicating a possible problem in the drainage generating slurry pockets. Thus, this project, besides studying the responses of the waste and how the geoelectric methods identify the geomembrane, it also investigates the presence of the pockets.

\section{Installation of experimental cell}

The installation of the experimental cell at the landfill Delta A was carried out by Benatti et al. (2013). It is located on top of the massive landfill Delta $A$, at elevation $630 \mathrm{~m}$, covering an area of $5,080 \mathrm{~m}^{2}$, and it is designed to receive solid domestic waste, classified in the categories of waste Class II-A and II-B (Fig. 2A). The project has a total volume capacity for waste disposal of 

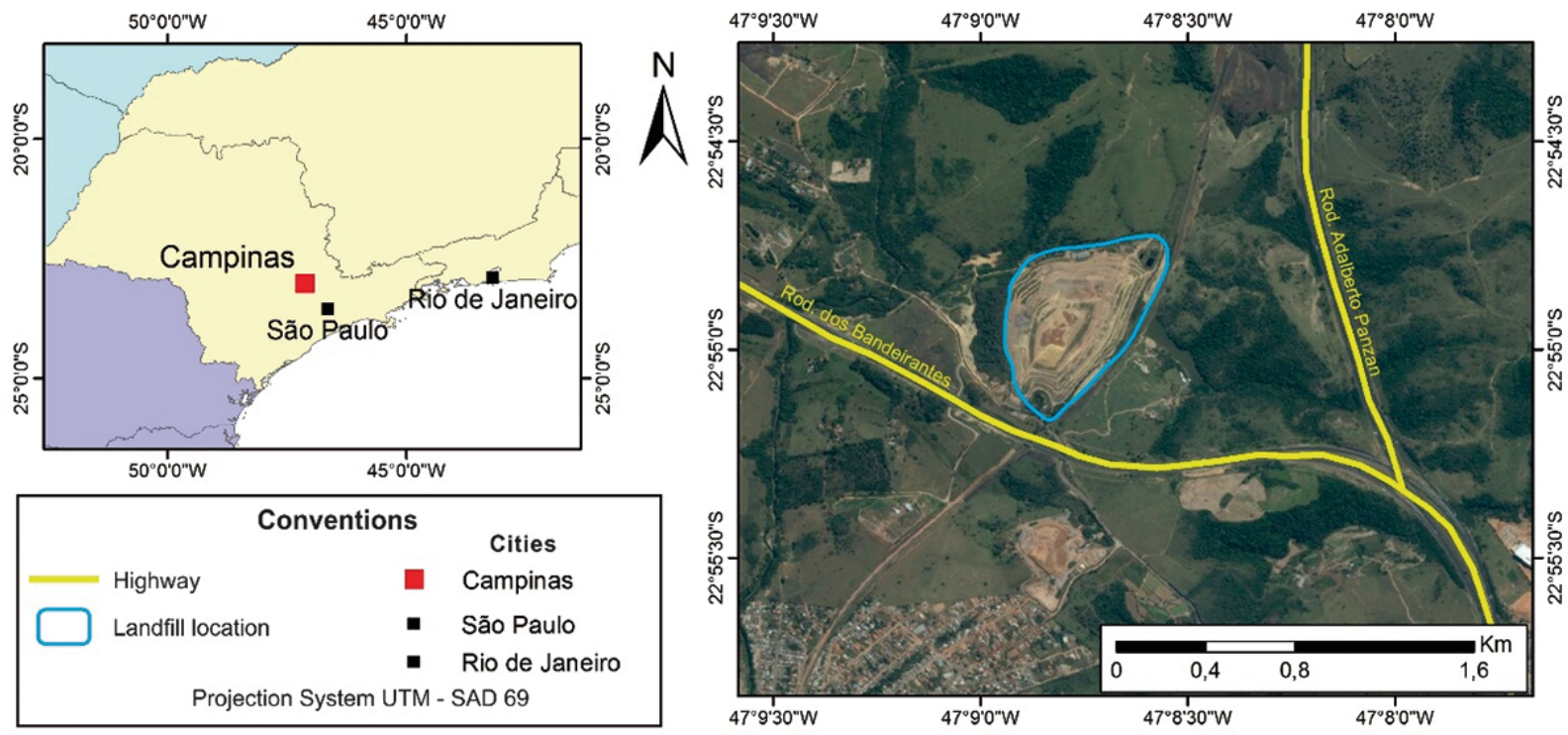

Figure 1 - Location of the municipal solid waste (MSW) landfill Delta A and its access roads.

approximately 15,000 cubic meters, and filling capacity of 20 days. The basic waterproofing system experimental cell was composed of a layer of compacted soil $50 \mathrm{~cm}$ thick HDPE geomembrane and non-woven geotextile.

A HDPE geomembrane with $1.5 \mathrm{~mm}$ thickness was installed over the compacted soil layer (Fig. 2B). Above the geomembrane was installed a geotextile non-woven $\left(300 \mathrm{~g} / \mathrm{m}^{2}\right)$ with mechanical protection of the geomembrane purpose. Over the geotextile is disposed a layer of sandy-silt with $10 \mathrm{~cm}$ thick, in order to offer thermo-mechanical protection of geosynthetics.

The leachate drainage system was performed with a $30.0 \mathrm{~cm}$ thick layer of gravel disposed over the entire base of the cell, including the central channel, with $30 \mathrm{~cm}$ deep and $2 \mathrm{~m}$ wide. This stage also included the execution of the flow measurement box. Figure $2 \mathrm{C}$ demonstrates the final stage of the drainage layer's installation.

The system of gas drainage was built with 5 drains with circular section and 1.5 meters of diameter, with screens that had a mesh of $10 \mathrm{~cm} \times 10 \mathrm{~cm}$, welded with a $4.2 \mathrm{~mm}$ wire. Each screen cylinder was filled with gravel and had at its center a drain tube (30 cm diameter) concrete perforated across its wall. Later, inside the piezometers tubes and the pressure vessels were installed gas collection system capable of collecting the gas produced in the five drains and direct it to a single point, where a device able to measure the gas flow must be installed. About a month before the waste disposal in the experimental cell, a campaign of gravimetric characterization of MSW has started.

Throughtout the procedure, 22 gravimetric characterization trials were performed, totaling $5500 \mathrm{~kg}$ of MSW characterized.
The experimental cell had its full operation performed only during the day. This choice was made in order to avoid shocks between crawler dozers and vertical gas drains, which are more usual at night due to lower visibility. To complete the filling, it was used only garbage trucks. During operation, two D-6 crawler dozers worked in the cell, which assisted in the opening of the trucks. Figure 2D shows the MSW compression stage within the cell.

The cover layer was composed of a layer of compacted soil with $50 \mathrm{~cm}$ thick. And the same soil of the base layer was used, originating from a mine located in the area of the landfill Delta $A$. Following the completion of this layer, 40 surfaces landmarks were installed over the cell.

\section{MATERIAL AND METHODS}

\section{Theoretical review}

The use of geophysical methods in landfills in order to map contamination plumes has increased over the years, the state and municipal bodies are widely interested in the results obtained by geophysical methods, given its indirect application and accurate results (Meju, 2000; Abu-Zeid et al., 2004; Stevanato et al., 2004; Johansson et al., 2007; Laureano \& Shiraiwa, 2008; Oliveira et al., 2011).

The direct current electrical resistivity method usually works with two currents ( $A$ and $B$ ) and two potentials ( $M$ and $N$ ) electrodes, all fixed onto the soil surface. A potential difference is applied between the electrodes $A$ and $B$ and, as a result, a direct electrical current travels through the soil. The current value is measured and recorded. The electrodes $\mathrm{M}$ and $\mathrm{N}$ are used to 


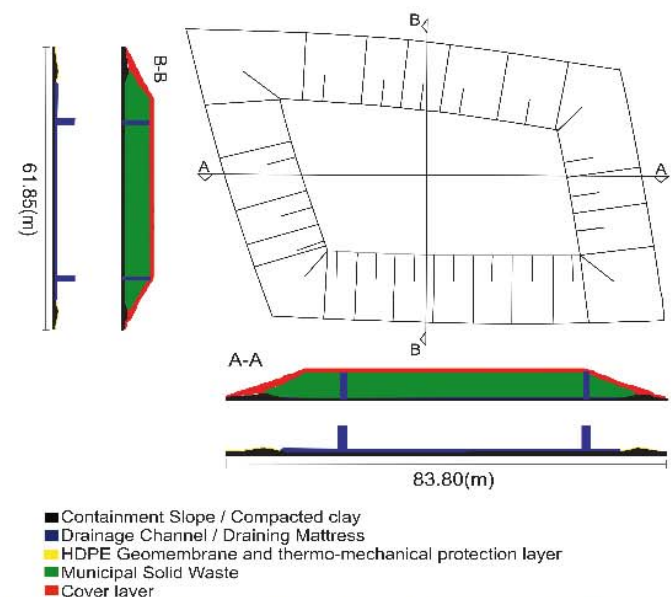

A
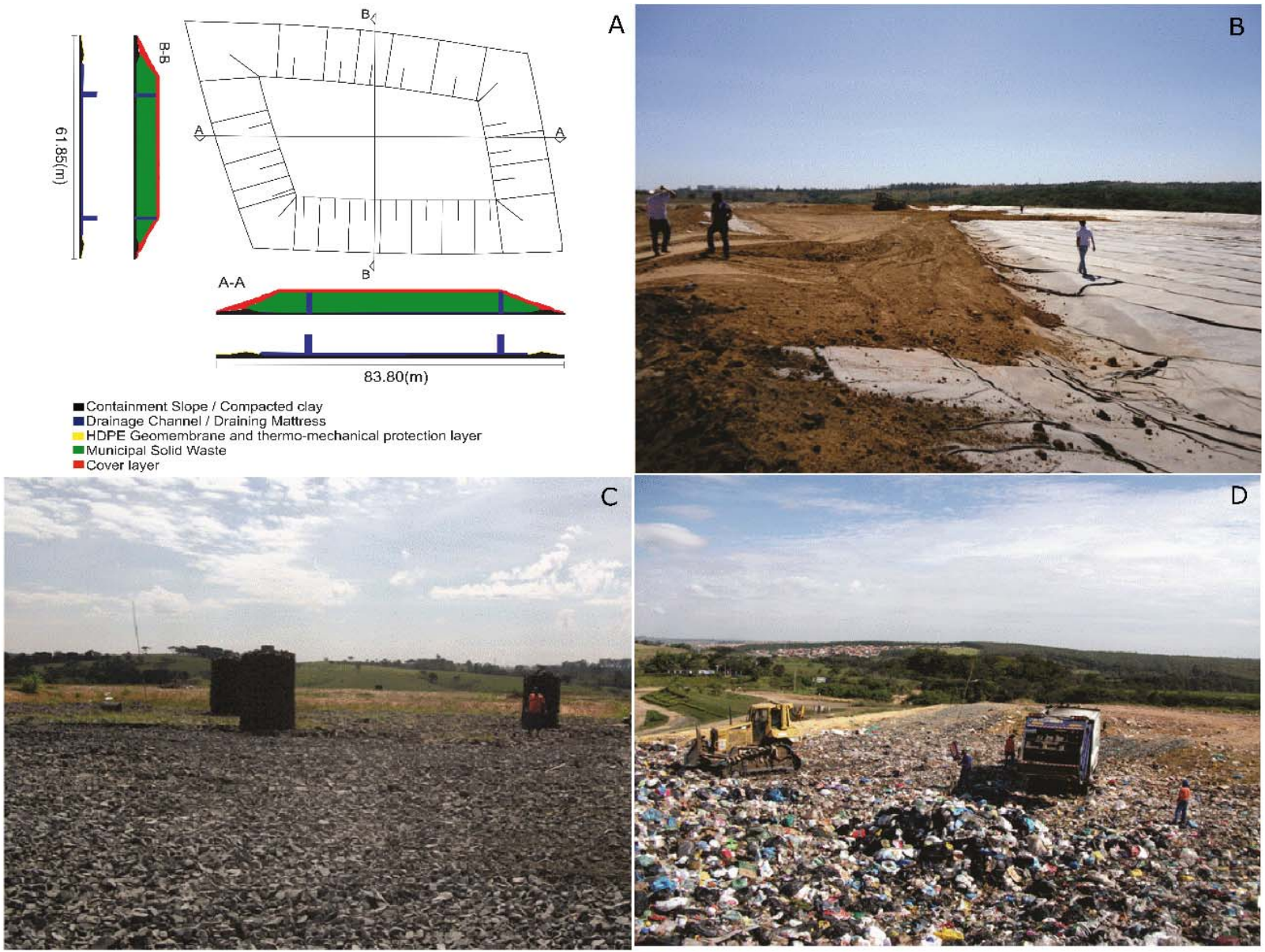

Figure 2 - Installation of the experimental cell. A) Implementation of the experimental cell at the MSW landfill Delta A. B) Geomembrane installation in the beginning of the implementation of the experimental cell. C) Drainage system completed. D) Compression of the MSW within the experimental cell. (Extracted from Benatti el al., 2013).

measure the potential difference that is established on soil and associated with the travelling current. It is noteworthy that the soil already has a natural electric potential, called spontaneous potential, which must be subtracted from the measurement between electrodes $\mathrm{M}$ and $\mathrm{N}$. Thus, knowing the current that travels the subsoil, the electrodes arrangement geometry and the potential measured between electrodes $\mathrm{M}$ and $\mathrm{N}$, it allows us to calculate an apparent electrical resistivity value named as such because it is measured in a heterogeneous and anisotropic medium as a function of the electrode array (Orellana, 1972; Telford et al., 1990).

The development of 2-D electrical imaging equipment was accompanied by the development of specific computer software to represent this type of measurement, such as RES2DINV (Loke \& Barker, 1996a; 1996b). This software inverts the set of measures, i.e., allows to build a subsurface geoelectrical model, whose response to the energization reproduces, as best as possible, the measurements obtained. This geoelectrical model is subsequently interpreted in terms of the geological/hydrogeological/pedological model that fits best the studied area.

\section{DATA ACQUISITION AND PROCESSING}

During the field work the geophysical equipment used was the device which combines Syscal R2 Plus transmitter (Tx) and Syscal Elrec Pro receiver (Rx), powered by a $12 \mathrm{~V}$ battery (Fig. 3) and whose specifications include output voltage up to $1000 \mathrm{~V}$. The equipment has a microprocessor-controlled electronic circuits that perform operations internally (Rx), such as the calculation of resistivity averages and, in addition, perform checks on the circuit before showing the result and it is a multichannel equipment which allows multiple potential dipoles to be used simultaneously in order to obtain the resistivity measurements (Tx).

The dipole-dipole array was used for data acquisition, this arrangement presents spaces between the centers of the dipoles 


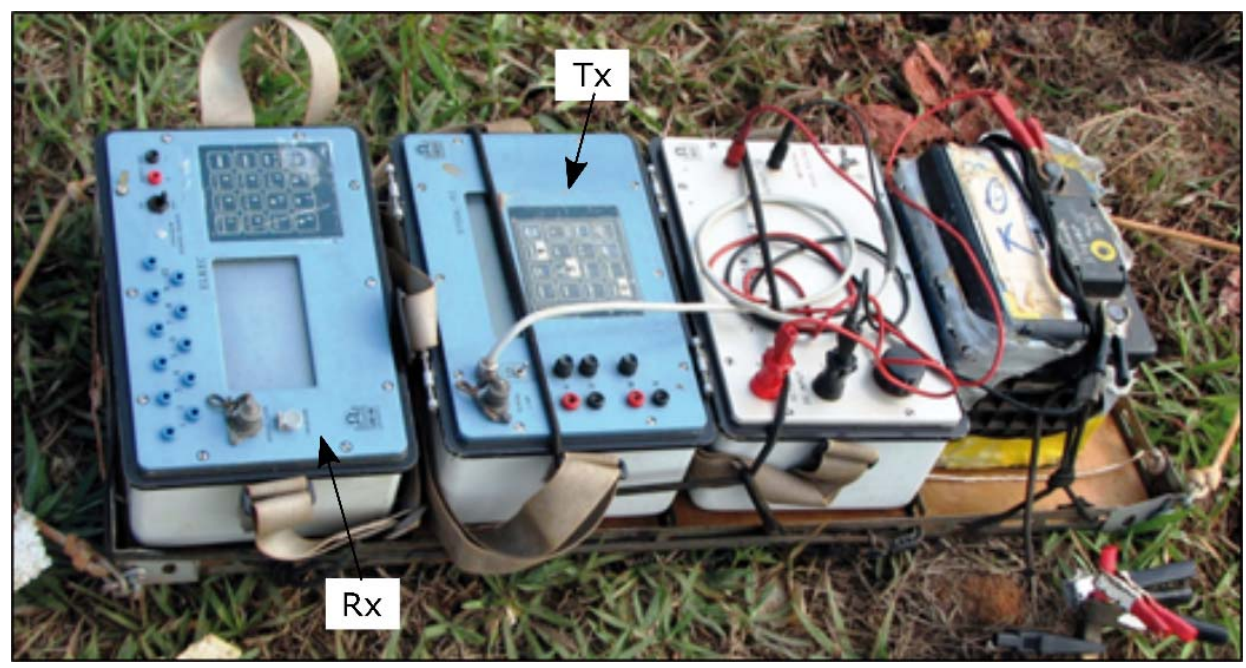

Figure 3 - Resistivity meter Iris Syscal R2 Plus (Tx), Syscal Elrec Pro conversor and voltage converter (Rx) and 12 V battery used in the acquisition.

( $A B$ and $M N$ ), variable along the raised line, and for each level of research (theoretical depth) a particual spacing of dipolar surface is given. Other particularities of the dipole-dipole array are the distances between the current electrodes $\mathrm{A}$ and $\mathrm{B}$, that are equal to the potential electrodes $\mathrm{M}$ and $\mathrm{N}$.

Typically, measurements are performed at several depths of investigation, i.e. $n=1,2,3,4$ and 5, assigned at the intersection of lines that run from the center of $A B$ and $M N$ with 45 degree angles (Fig. 4). The obtained data represented by the letter $L$ in the equation are plotted in the positions $n=1,2,3,4$ and 5, and interpolated, generating an apparent resistivity pseudo-section. Equation (1) is used to calculate the apparent resistivity.

$$
\begin{gathered}
\rho a K=\Delta V / I \\
K=2 \pi \cdot L \cdot X \\
L=1 /[(1 / n)-(2 / n+1)+(1 / n+2)]
\end{gathered}
$$

$\rho a=$ apparent resistivity (ohm.m);

$K=$ geometric factor for the used arrangement (m);

$\Delta V / I=$ electrical resistance (ohm.m);

$L=$ distance of the multiple dipoles (typically $n=1,2,3,4$ and 5);

$X=$ distance moved by dipoles $(\mathrm{m})$;

$\pi=3.1415$;

$\Delta V=$ difference in electric potential $(\mathrm{mV})$;

$I=$ electrical current $(\mathrm{mA})$.

The electrical profiling (EP) technique was applied distributed in 6 lines (Fig. 5), with a length of $100 \mathrm{~m}$ and $12 \mathrm{~m}$ spaced between the lines. It is used the dipole-dipole array with electrode spacing of $4 \mathrm{~m}$ (lines $\mathrm{C} 1$ and $\mathrm{C2}$ ) and $5 \mathrm{~m}$ other lines, thereby obtaining 9 theoretical levels of investigation.

All the data have been processed jointly using the RES2DINV software (Loke \& Barker, op. cit.). This software adopts a rapid technique for inverting apparent resistivity data into actual resistivity, which is much more useful for geological interpretation. Theoretically, it produces a subsurface geoelectrical 2-D model free of the distortions from the pseudo-sections of apparent resistivity caused by the geometry array used.

\section{D FORWARD MODELING}

In order to compare hypothetical situations with real data field, synthetic models were created to portray the situations found in the experimental cell. All modeling used the RESIXIP2Di v3 software (Interpex, 1996), which calculates the theoretical responses from geoelectrical model with the method of "Finite Elements" (Rijo, 1977) and 2D inversion method used "Simple Least-Squares" (Inman, 1975).

The synthetic model is constructed from a section of rectangular cells ("grid") that extend laterally to the first current electrode to the last potential electrode. Subsequently, each rectangle is divided into four triangles to generate a finite element mesh. In this mesh, during a polygonal modeling, allowed the construction of several polygons in which values of resistivity and dimensions are assigned.

Thus in polygonal modeling the interpreter defines a background value and several polygons, each containing constant values of resistivity, so that the values of the triangles of the finite element mesh contained within the polygons become uniform, as well as those of the background. 


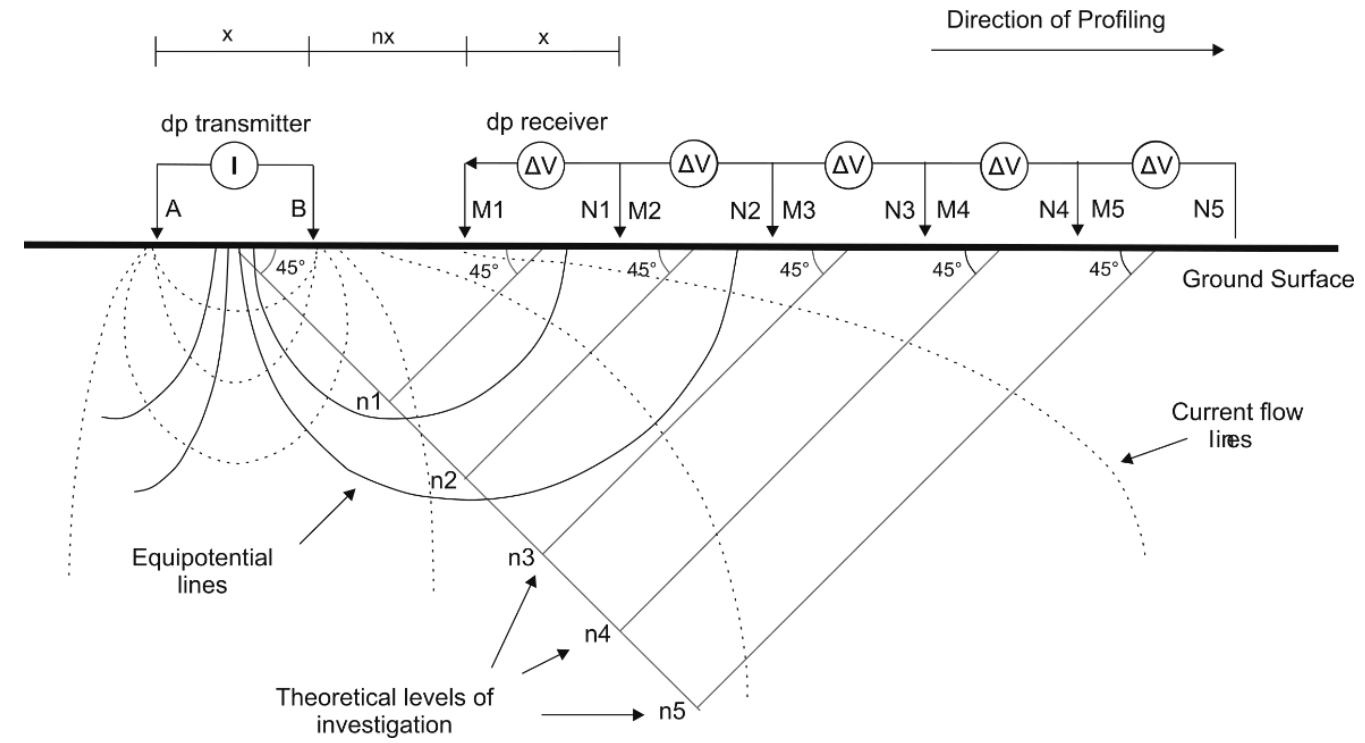

Figure 4 - Arrangement scheme dipole-dipole used in the electrical profiling technique. The dotted lines represent the current flow lines and the full lines the equipotential lines. The letter " $n$ " represent the theoretical levels of investigation ( $n 1$ to n5). Letters " $x$ " and " $n x$ " represent the distance between transmitter electrodes $A$ and $B$, and the distance between transmiting dipole to receiving dipole. (Adapted from Braga, 2016).

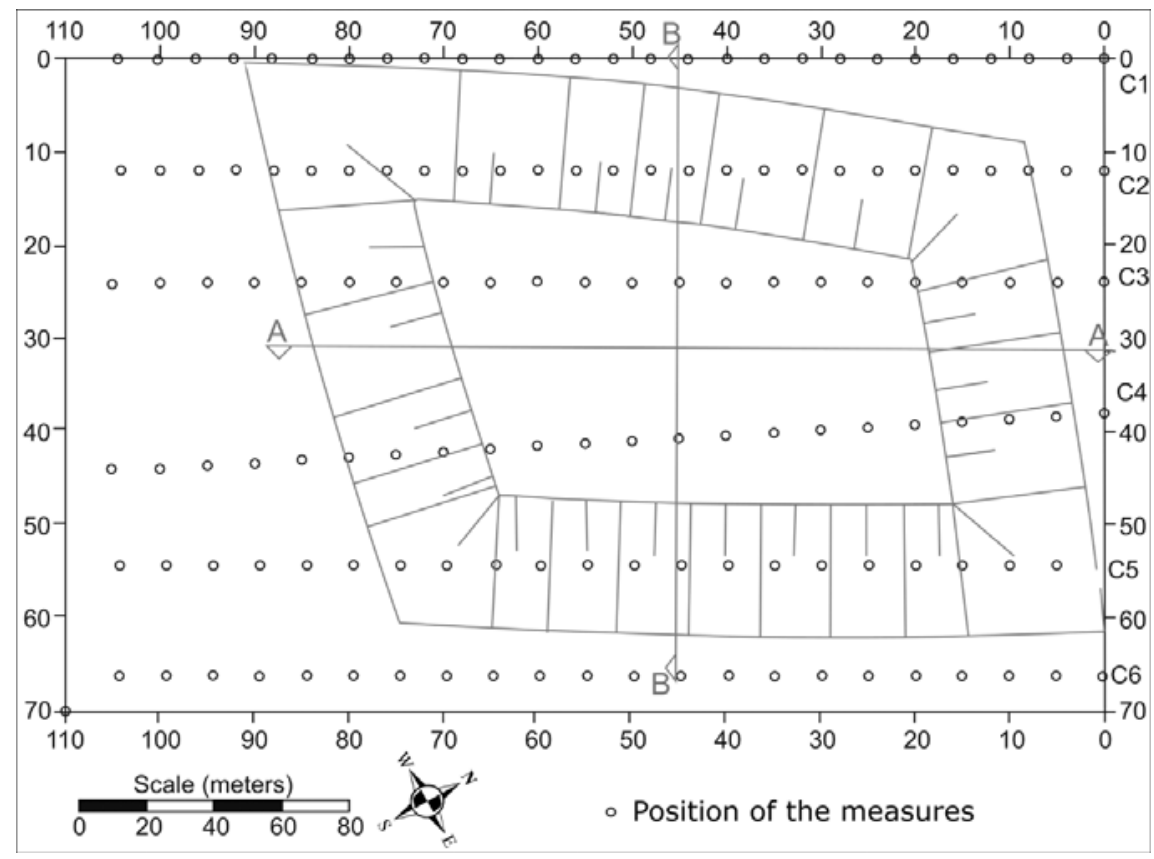

Figure 5 - Distribution of six lines (C1, C2, C3, C4, C5 and C6) of EP technique covering the experimental cell. The empty circles represent the position of the measures and the direction of the survey vary to NE-SW to SW-NE.

During the simulation of the model, the current is injected into each node of the mesh to the theoretical depths defined by the grid and the current electrodes are responsible for generating the voltages at the potential electrodes. The interpreter provides the program with information about the field arrangement and electrode positions, so that the combined results provide the apparent resistivity values in the pseudo-section.

Once understood the working process of the mechanism, the stage of the model's creation, was performed. At this stage, information such as size and position of targets, the type of 


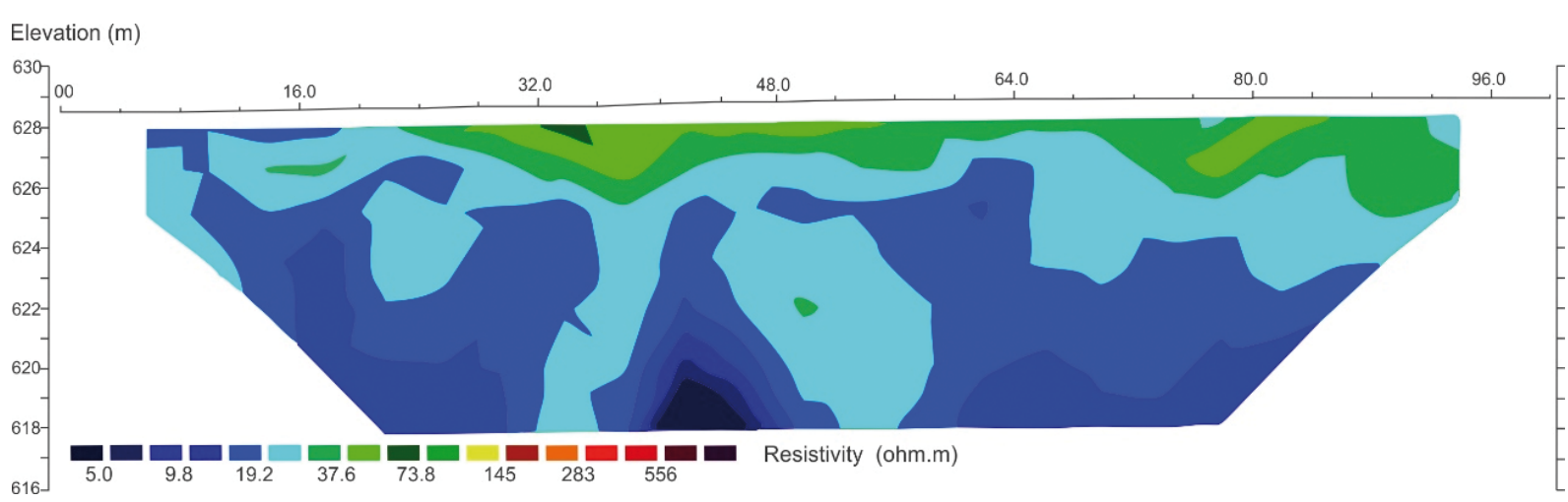

Figure 6 - 2D Profile modeled resistivity (ohm.m) corresponding to the line 1-C1 (out of the experimental cell).

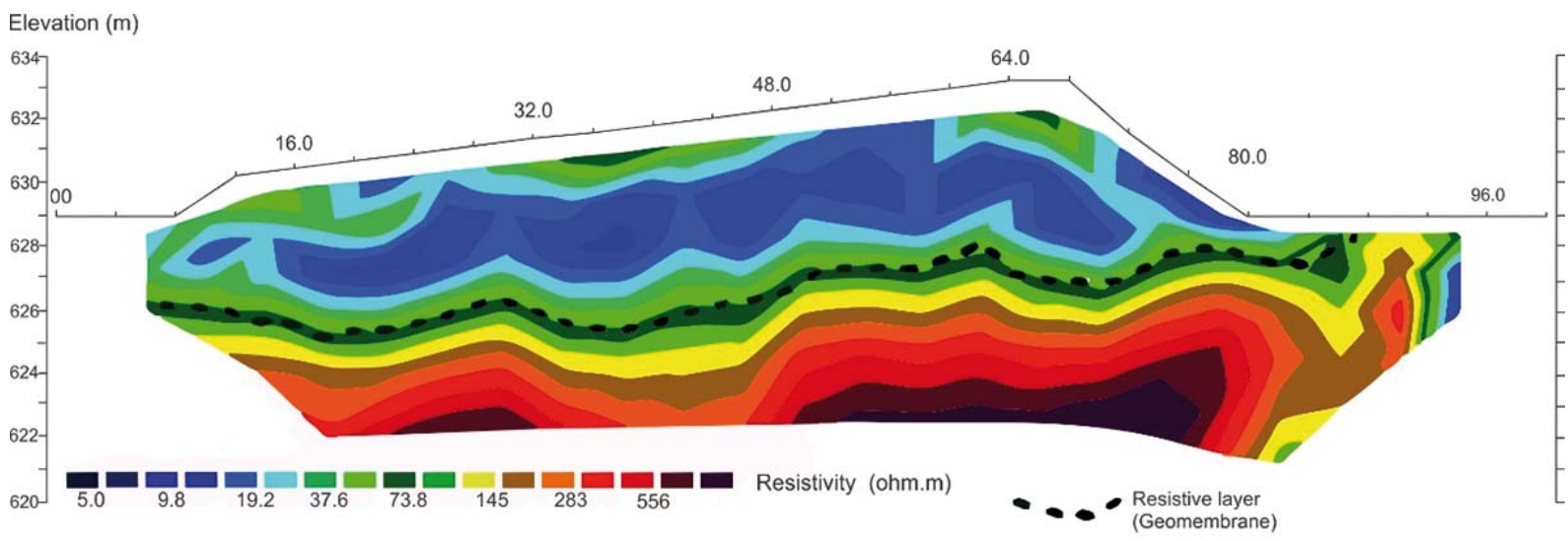

Figure 7-2D profile modeled resistivity (ohm.m) corresponding to the line $2-\mathrm{C} 2$. The dotted line represents the resistive layer (geomembrane).

arrangement (dipole-dipole), the opening of the dipole and resistivity values (parameters used in the simulations) assigned to the targets and background, were supplied to the program. The assignment of values for the resistivity model was made respecting the characteristics of the targets.

During the simulations, resistivity values were indicated for later be used in profiling the slurry and HDPE geomembrane, being $1.5 \mathrm{ohm} . \mathrm{m}$ to $25 \mathrm{ohm} . \mathrm{m}$ for the characterization of slurry and 100,000 ohm.m representing the geomembrane. And finally, we made three synthetic models using RESIXIP2DI software in order to simulate certain events and compare them with the actual results from the data collected in the field.

\section{RESULTS}

\section{Electrical Profiling Technique}

In line 1, performed on the NW outer edge of experimental cell and directly on the landfill, we have low resistivity values that rarely vary ( $<25$ ohm.m), due to the position directly over the waste (Fig. 6). Near the surface we have a band with slightly higher resistivity (ohm.m 37) corresponding to the ground cover.
Line 2 was held on the edge of the cell and is shown in Figure 7. The dashed line indicates the interface between the residues and the geomembrane. In this line we have resistivity values in a range from 10 to 75 ohm.m corresponding to the municipal solid waste (MSW) and also out the ground cover layer in some areas. Below the body of waste, where the geomembrane is located, there are high resistivity values (which are up to $>500$ ohm.m). The geomembrane is an insulating body, so there is no penetration of electrical current below it, and as a result (due to the concept of apparent resistivity) has a highly resistive layer that does not match the geometry and real resistivity of the experimental cell.

In Figures 8 and 9 we see the results of lines 3 and 4, and we can notice an approximately constant level with resistivities less than 70 ohm.m which indicates the level of slurry within the body of waste. Some lower resistivity regions $10 \mathrm{ohm} . \mathrm{m}$ (in dark blue) may correspond to a slurry buildup.

In line 5 (Fig. 10), we have a similar result to the previous lines with values $<70$ ohm.m corresponding to the accumulation of slurry above the geomembrane, we can also see areas where slurry accumulation represented values ranging from 5 to 


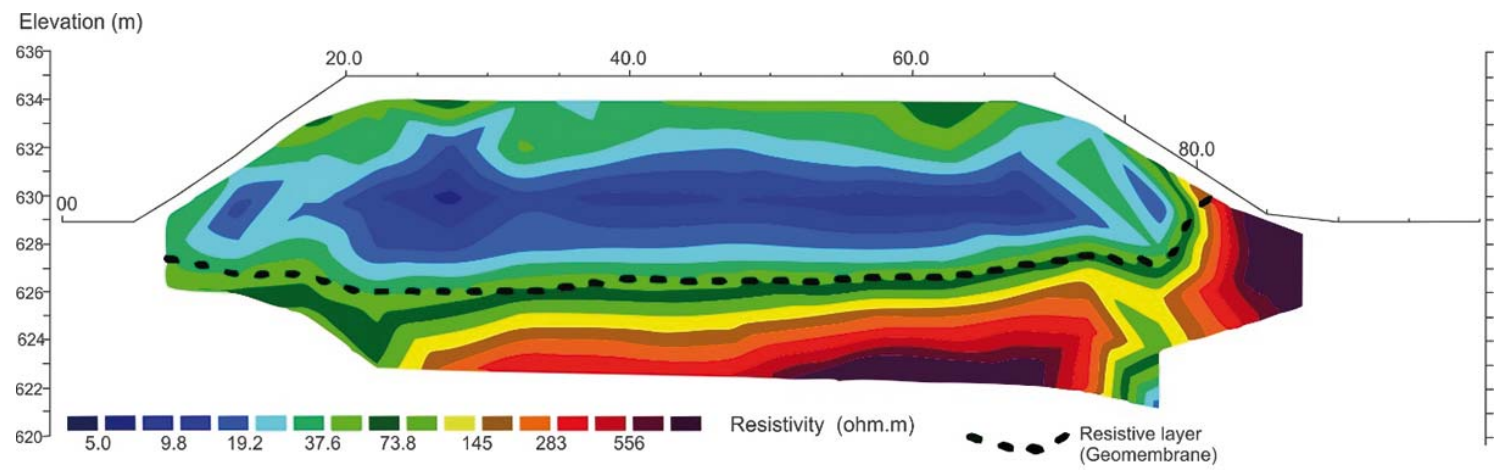

Figure 8 -2D profile modeled resistivity (ohm.m) corresponding to the line 3-C3. The dotted line represents the resistive layer (geomembrane).

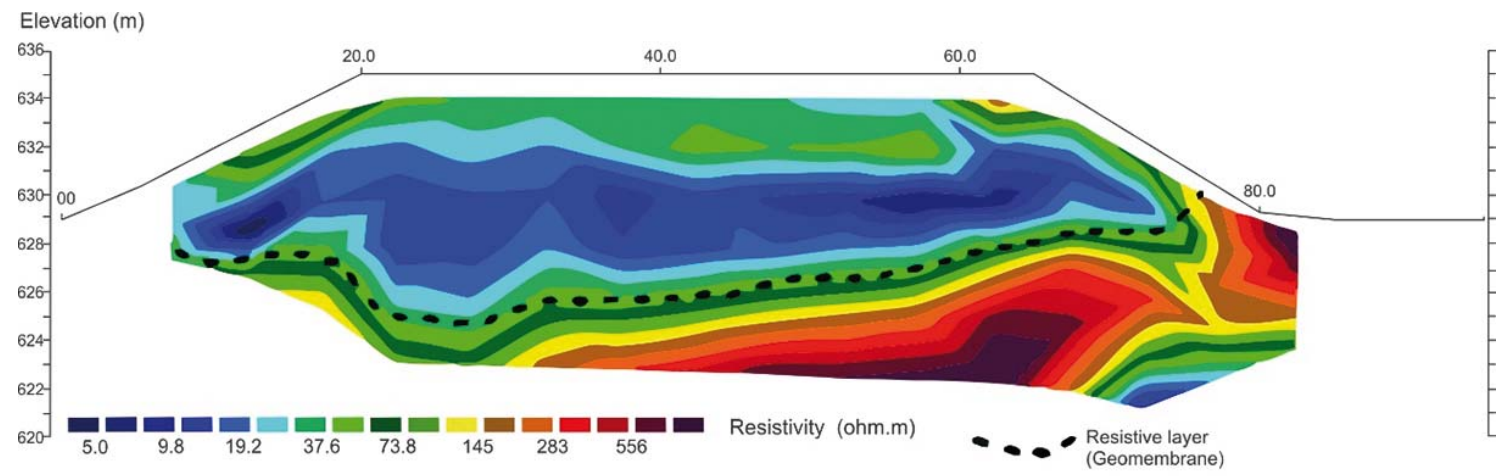

Figure 9-2D profile modeled resistivity (ohm.m) corresponding to the line 4-C4. The dotted line represents the resistive layer (geomembrane).

10 ohm.m, the interface between the cell and geomembrane is once again marked by different resistivity values, since below the impermeable layer values are too high $>145$ ohm.m reaching $>500$ ohm.m.

The line 6 (Fig. 11) was performed on the SE outer edge of the experimental cell as well as the line 1 out of the geomembrane limits. Resistivity values vary slightly (10 to $40 \mathrm{ohm} . \mathrm{m}$ ) also has low resistivity areas ( $<10 \mathrm{ohm} . \mathrm{m}$ ), which may indicate the buildup of slurry. EP data collected in the field were processed and filtered using RES2DINV software, which provided the modeled resistivity sections.

\section{D forward modeling}

In parallel to the real geoelectric results obtained in the field three synthetic models of experimental cell behavior were made, simulating certain situations. For it, was used the RESIXIP2Di software which allows this type of interaction. Synthetic models were compared to the actual model, permiting a statement interpretation of the most likely situation found in the field.

In Figure 12 ( $A$ and $B$ ), we have a model of experimental cell with the installation of the geomembrane, in this model we can see that three resistivity values are defined, and $5 \mathrm{ohm} . \mathrm{m}$ inside the cell, 25 ohm.m in depth and 100,000 ohm.m for the geomembrane. A resistivity section in RES2DINV with these values was generated. In Figure 13 ( $A$ and $B$ ) we model the experimental cell with the installation of the geomembrane and slurry levels inside the cell, in this model we can see that four resistivity values are defined, 1.5 and $25 \mathrm{ohm} . \mathrm{m}$ inside the cell and $25 \mathrm{ohm} . \mathrm{m}$ in depth and 100,000 ohm.m to geomembrane.

In Figure 14 ( $A$ and $B$ ) we have the model of the experimental cell with the installation of the geomembrane, with slurry levels inside the cell, with $1 \mathrm{~m}$ diameter hole at the center and leakage slurry. This model was designed with small proportions diameter hole and a plume of major proportions, in order to represent as best as possible a real leaking slurry. We can observe that four resistivity values are defined, 5 ohm.m inside the cell and for the slurry leakage $25 \mathrm{ohm} . \mathrm{m}$ and another level of slurry inside the cell with 35 ohm.m in depth and to 100,000 ohm.m for the geomembrane. In this model, the objective was to determine how would the resistivity values behave when there was disruption of the geomembrane and leachate leakage below the limits of the experimental cell. 


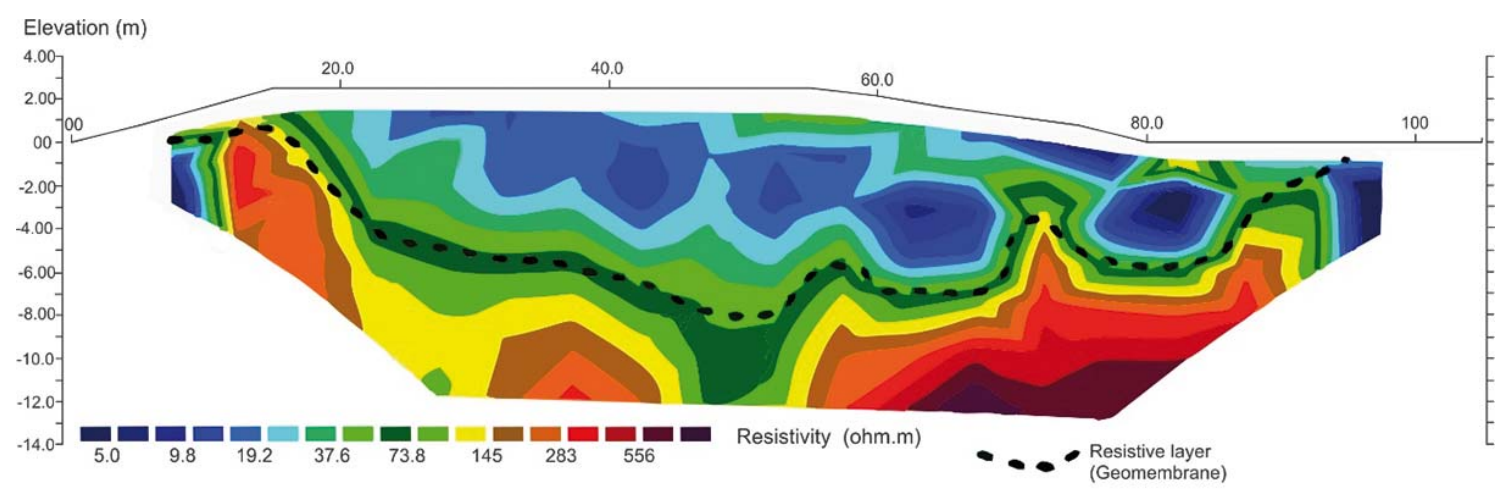

Figure 10 -2D profile modeled resistivity (ohm.m) corresponding to the line 5-C5. The dotted line represents the resistive layer (geomembrane).

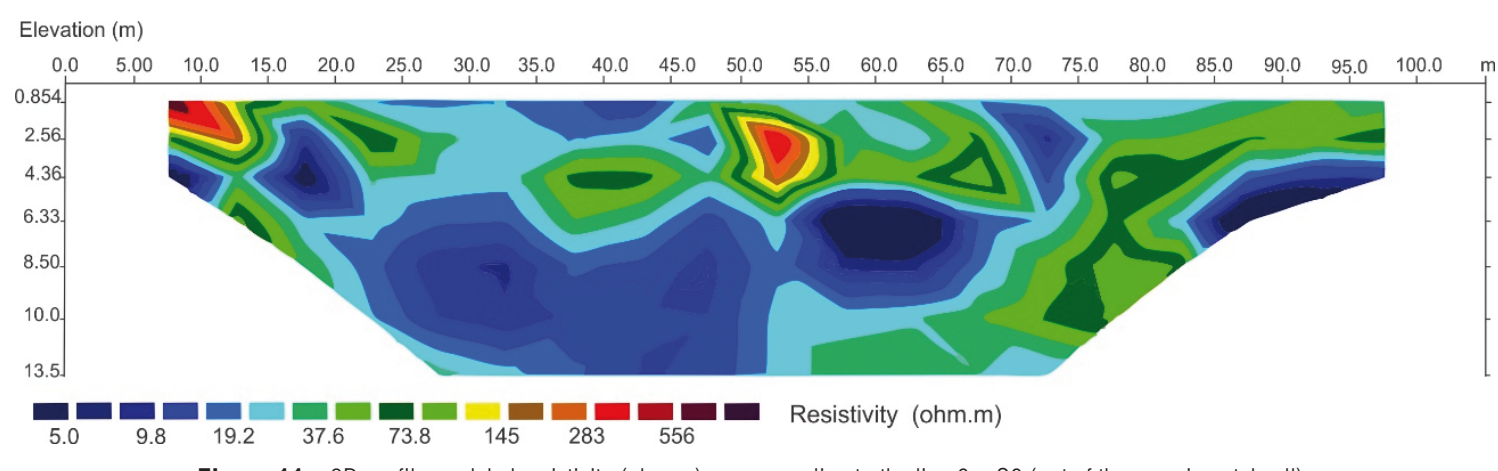

Figure 11-2D profile modeled resistivity (ohm.m) corresponding to the line 6- C6 (out of the experimental cell).

Therefore, combining field data and the data collected in the simulations it can affirm that there is not a leakage of slurry below the geosynthetic layer and what really happens its a slurry accumulation in the experimental cell in a heterogeneously form, represented by variation in the resistivity values in the middle. It can say that the model in Figure 13 ( $A$ and $B$ ) is close to that found at the local of research.

\section{DISCUSSION AND CONCLUSIONS}

The results obtained validate the use of geoelectrical methods in the characterization and mapping of contamination in environmental applications. The EP technique provided information on the experimental cell, identifying the resistive layer (geomembrane) which allowed us to compare the field data with simulations in the laboratory. Although, the method is limited by the resistive layer, it is not possible to verify the actual resistivity below the geomembrane, due to its insulating effect. From the simulations obtained through mathematical modeling, the one that corresponded the most with the actual data field was the one with leachate levels and application of geomembrane (Fig. 13), its resistivity profile is very close to that found in Fig- ures 7, 8, 9 and 10 from the resistivity profiles. Some combined results located have a very low resistivity suggesting zones with slurry concentration, confirming the indications of the cell monitoring wells. Therefore, using the EP technique, it was possible to identify the geomembrane (resistive layer) in the electroresistivity profiles, as well as a synthetic model as a standard model (Fig. 13) for the study area and was delimited points of accumulation of slurry. Subsequently, due to the concentrations of slurry generating points of high conductivity values, it is advisable to use other methodologies such as the ground penetrating radar (GPR), due to the continuity of its profiles and the high resolution obtained and the electromagnetic method (EM-34), to compare the data obtained with the method used in this survey.

\section{ACKNOWLEDGEMENTS}

The authors are thankful to the National Council for Scientific and Technological Development (CNPq) for the scholarship granted during the period of the master's degree at Institute of Astronomy, Geophysics and Atmospheric Sciences - University of São Paulo (IAG-USP). To Institute of Technological Research (IPT), and especially to Dr. Otávio Coaracy Brasil Gandolfo. 

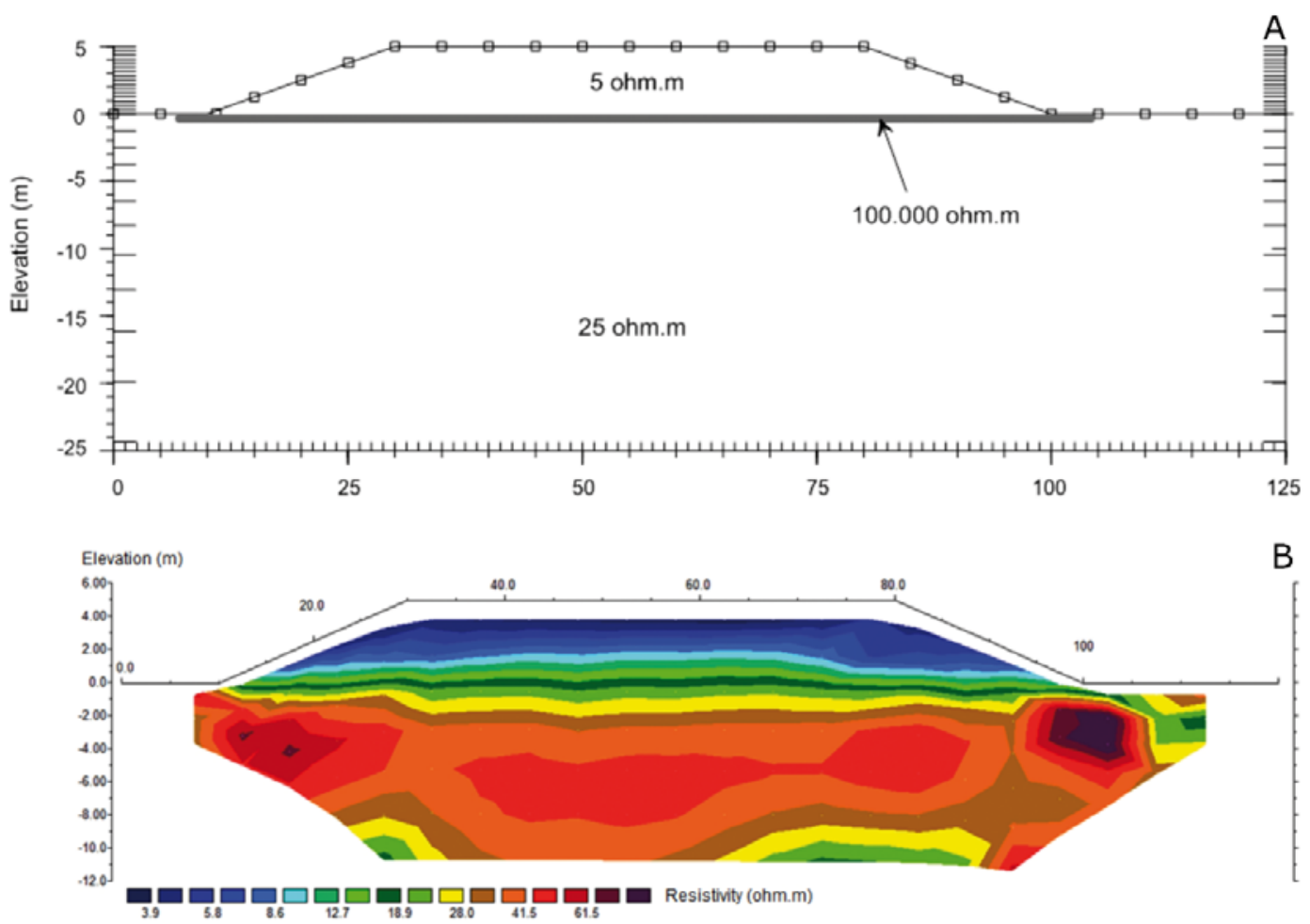

Figure 12 -2D forward modeling. A) Synthetic model of the experimental cell with application of geomembrane. B) Resistivity section obtained from modeling data.
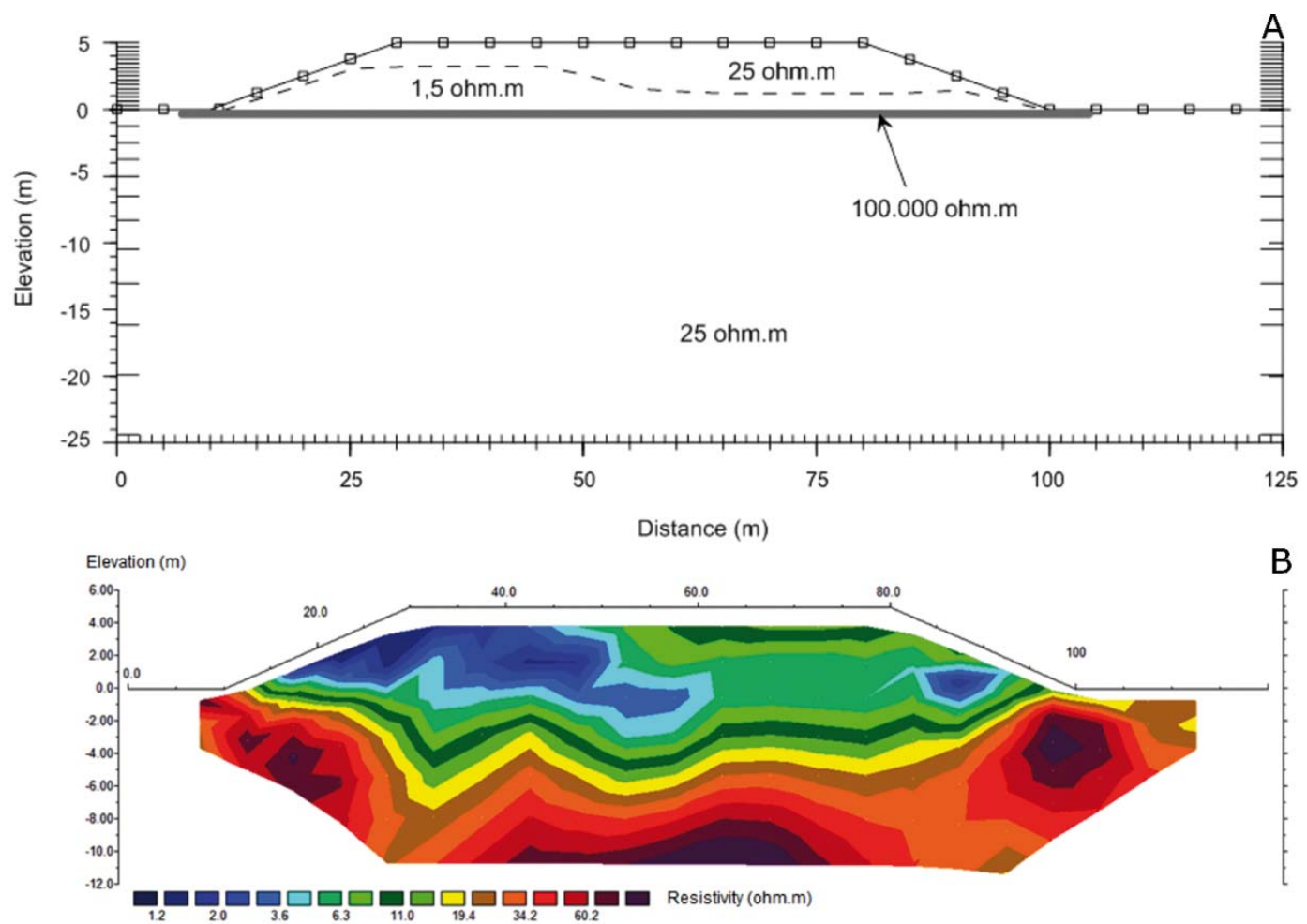

Figure 13-2D forward modeling. A) Synthetic model of experimental cell with application of geomembrane and leachate levels. B) Resistivity section obtained from modeling data. 


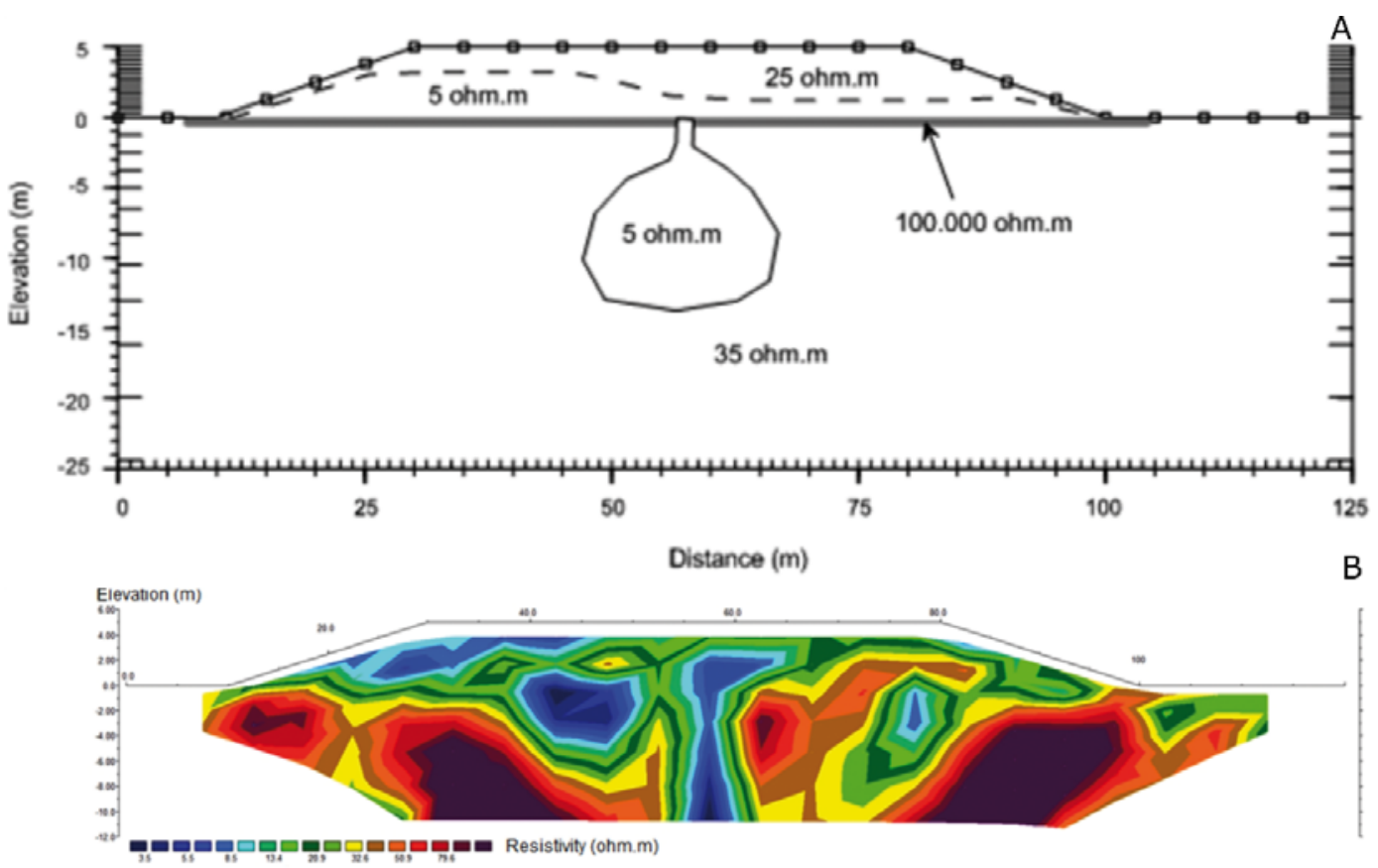

Figure 14-2D forward modeling. A) Synthetic model of the experimental cell with application of geomembrane, leachate levels and central hole with leachate leaking. B) Resistivity section obtained from modeling data.

\section{REFERENCES}

ABRELPE - Associação Brasileira de Empresas de Limpeza Pública e Resíduos Especiais. 2012. Panorama dos Resíduos Sólidos no Brasil. São Paulo, Brazil.

ABU-ZEID N, BIANCHINI G, SANTARATO G \& VACCARO C. 2004. Geochemical characterisation and geophysical mapping of Landfill leachates: the Marozzo canal case study (NE Italy). Environmental Geology, 45(4): 439-447.

BENATTI JCB, PAIXÃO FILHO JL, GABRIELI G, LEME MAG, ELAIUY MLC, TEIXEIRA EN, PEREIRA SY \& MIGUEL MG. 2013. Parceria para Implantação de uma Célula Experimental de Resíduos Sólidos Urbanos de Grandes Dimensões, 01/2013. In: III Conferência Internacional de Gestão de Resíduos na América Latina. São Paulo, SP, Brazil. 10 pp.

BRAGA AC0. 2016. Métodos Geoelétricos em Hidrogeologia. Ed. Oficina de Textos. São Paulo, Brazil, 159 pp.

CETESB - Companhia de Tecnologia de Saneamento Ambiental. 2001. Manual de gerenciamento de áreas contaminadas. GTZ. 2 ed., São Paulo, Brazil, 389 pp.

IBGE - Instituto Brasileiro de Geografia e Estatística. 2010. Pesquisa Nacional de Saneamento Básico, 2008. Rio de Janeiro, Brazil.

INMAN JR. 1975. Resistivity Inversion with Ridge Regression. Geophysics, 40: 798-817.
INTERPEX. 1996. RESIXIP2DI v. 3.0. DC resistivity and induced polarization data interpretation software. USA. Manual.

JOHANSSON B, JONES S, DAHLIN T \& FLYHAMMAR P. 2007. Comparisons of 2D- and 3D-inverted resistivity data as well as of resistivityand IP-surveys on a landfill. In: European Meeting of Environmental and Engineering Geophysics. EAGE, Istanbul, Turkey. P42.

LAUREANO AT \& SHIRAIWA S. 2008. Ensaios geofísicos no aterro sanitário de Cuiabá-MT. Brazilian Journal of Geophysics, 26(2): 173180.

LOKE MH \& BARKER RD. 1996a. Rapid least-squares inversion of apparent resistivity pseudosections by a quasi-Newton method. Geophysical Prospecting, 44: 131-152.

LOKE MH \& BARKER RD. 1996b. Practical techniques for 3D resistivity surveys and data inversion. Geophysical Prospecting, 44: 499-523.

MEJU MA. 2000. Geoelectrical investigation of old/abandoned, covered landfill sites in urban areas: model development with a genetic diagnosis approach. Journal of Applied Geophysics, 44(2-3): 115-150.

OLIVEIRA S \& PASQUAL A. 2004. Avaliação de parâmetros indicadores de poluição por efluente líquido de aterro sanitário. Engenharia Sanitária e Ambiental, 9(3): 240-249.

OLIVEIRA MT, MOREIRA CA \& MENEZES AMC. 2011. Aplicação do método de Polarização Induzida em área de disposição de resíduos 
sólidos no município de Caçapava do Sul - RS. Brazilian Journal of Geophysics, 29(2): 377-384.

ORELLANA E. 1972. Prospeccion geoelectrica en corriente continua. Madrid: Ed. Paraninfo, Biblioteca Técnica Philips, 523 pp.

POSSAMAI FP, VIANA E, SCHULZ HE, COSTA MM \& CASAGRANDE E. 2007. Lixões inativos na região carbonífera de Santa Catarina: análise dos riscos à saúde pública e ao meio ambiente. Ciência e Saúde Coletiva, 12(1): 171-179.

RIJO L. 1977. Prospecção geofísica nas regiões de Ponta de Pedra e Soure na Ilha de Marajó. In: Simpósio de Geologia do Nordeste, 8., 1977,
Campina Grande. Campina Grande: Sociedade Brasileira de Geologia, Núcleo Nordeste, p. 58-59.

STEVANATOR, FONSECA FERREIRA FJ, WOSNIAK R \& SIMIONI MTS. 2004. Mapeamento de pluma de contaminação no aterro sanitário de Coronel Vivida-PR. In: I Simpósio Brasileiro de Geofísica. São Paulo: SBGf, Brazil. CD-ROM.

TELFORDWM, GELDART LP \& SHERIFF RE. 1990. Applied Geophysics. 2nd ed., Nova York: Cambridge University Press, 770 pp.

UNEP-EEA. 2007. The Road from landfilling to recycling: common destination, different routes. European Environment Agency, 20 pp.

Recebido em 12 maio, 2016 / Aceito em 26 junho, 2017

Received on May 12, 2016 / Accepted on June 26, 2017 